\section{Loyalitas Kreativitas \\ Aldi Masyarakat Kreatif}

P-ISSN 2722-2101, E-ISSN 2722-4201

Program Studi Ekonomi Manajemen Universitas Pamulang

Jurnal LOKABMAS Kreatif Vol. 01, No. 03, Hal.53-62

Email:jurnalkreatif.manajemen@gmail.com

\title{
PKM LEGALISASI KOPERASI KEPADA PENGURUS KOPERASI PESONA MANDIRI PASAR MINGGU, JAKARTA SELATAN
}

\author{
Siswi Wulandari, Rully Noor Oktaviana \\ Dosen Pendidikan Ekonomi, Universitas Indraprasta PGRI Jakarta \\ siswiwulandari89@gmail.com.ully.unpam@gmail.com
}

\begin{abstract}
ABSTRAK
Pengabdian ini berjudul PKM Legalisasi Koperasi Kepada Pengurus Koperasi Pesona Mandiri Pasar Minggu, Jakarta Selatan.

Kegiatan Pengabdian Masyarakat ini bertujuan untuk memberikan informasi serta mendorong para Pengurus Koperasi Pesona Mandiri agar segera melakukan legalisasi erhadap Koperasi mereka. Karena dengan legalisasi maka Koperasi tersebut akan berstatus badan hukum. Target rencana proyek ini salah satu dari Tri Dharma Perguruan Tinggi yaitu Pengabdian Kepada Masyarakat. Metode yang digunakan dalam beberapa kegiatan yaitu tahap survey yaitu sosialisasi dilakukan dengan menyusun hal yang akan disampaikan pada saat pelaksanaan kegiatan pengabdian, yang meliputi: penyusunan materi, penyusunan jadwal pemberian materi, pembagian tugas tim, dan survey ke lokasi pengabdian. Tahap sosialisasi yaitu sebelum kegiatan pengabdian dilaksanakan terlebih dahulu dilakukan silaturahmi kepada pengurus Koperasi Pesona Mandiri, menyampaikan maksud dan tujuan pengabdian ini. Pada tahap ini juga dilakukan jalinan kerjasama dan menentukan jadwal kegiatan pengabdian. Tim pelaksana pengabdian ini adalah oleh Tim Dosen Universitas Indraprasta PGRI sebanyak dua orang. Tim memberikan ceramah mengenai badan hukum dan legalisasi, penyuluhan urgensi legalisasi koperasi, kemudian dilanjutkan dengan memberikan informasi dalam melakukan legalisasi Koperasi menjadi sebuah badan hukum.

Hasil pengabdian masyarakat yang diperoleh adalah bertambahnya pengetahuan peserta mengenai badan hokum, legalisasi dan manfaatnya untuk koperasi. Selain itu kegiatan ini menghasilkan luaran berupa artikel Pengabdian Kepada Masyarakat yang akan berguna bagi rekan-rekan dosen lainnya yang mungkin saja menemukan permasalahan yang sama terkait Koperasi di daerah tempat tinggalnya. Melalui pemberdayaan ini diharapkan dapat merubah pola pikir pengurus Koperasi bahwasanya kegiatan Koperasi akan legal apabila Koperasi telah di legalisasi dan berbentuk badan hukum.
\end{abstract}

Kata kunci: Koperasi, Legalisasi, Badan Hukum

\begin{abstract}
This service was entitled PKM Legalization of Cooperatives to the Management of the Pesona Mandiri Cooperative in Pasar Minggu, South Jakarta.

This Community Service activity aims to provide information and encourage the Management of the Pesona Mandiri Cooperative to immediately carry out legalization of their cooperative. Because with legalization, the cooperative will have the status of a legal entity. The target of this project plan is one of the Tri Dharma Perguruan Tinggi, namely Community Service. The method used in several activities, namely the survey stage, namely the socialization is carried out by arranging things that will be conveyed during the implementation of the service activities, which include: preparation of materials, preparation of material delivery schedules, division of team tasks, and surveys of service locations. The socialization stage, namely before the service activity is carried out, first a gathering is carried out with
\end{abstract}




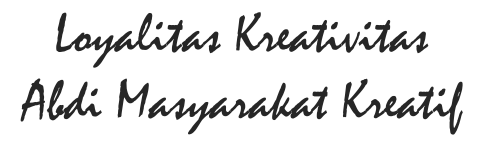

P-ISSN 2722-2101, E-ISSN 2722-4201

Program Studi Ekonomi Manajemen Universitas Pamulang

Jurnal LOKABMAS Kreatif Vol. 01, No. 03, Hal.53-62

Email:jurnalkreatif.manajemen@gmail.com

the management of the Pesona Mandiri Cooperative, conveying the aims and objectives of this service. At this stage, cooperation is also carried out and determines the schedule of service activities. The implementation team of this service is by the Lecturer Team of the Indraprasta PGRI University, consisting of two people. The team gave lectures on legal entities and legalization, counseled on the urgency of cooperative legalization, then continued by providing information on legalizing cooperatives into legal entities.

The result of community service obtained is the increase in participants' knowledge about legal entities, legalization and benefits for cooperatives. In addition, this activity produces an output in the form of Community Service articles that will be useful for other fellow lecturers who might find the same problems related to cooperatives in their area of residence. Through this empowerment, it is hoped that it can change the mindset of cooperative managers that cooperative activities will be legal if the cooperative has been legalized and is in the form of a legal entity.

\section{Keywords: Cooperative, Legalization, Legal Entity}

\section{PENDAHULUAN}

Menurut Pasal 1 Undang-undang Nomor

25 Tahun 1992 tentang Perkoperasian menyebutkan bahwa Koperasi adalah badan usaha yang beranggotakan orang-seorang atau badan hukum Koperasi dengan melandaskan kegiatannya berdasarkan prinsip Koperasi sekaligus sebagai gerakan ekonomi rakyat yang berdasar atas asas kekeluargaan.

Fungsi dan peran Koperasi adalah:

1. membangun dan mengembangkan potensi dan kemampuan ekonomi anggota pada khususnya dan masyarakat pada umumnya untuk meningkatkan kesejahteraan ekonomi dan sosialnya;

2. berperan serta secara aktif dalam upaya mempertinggi kualitas kehidupan manusia dan masyarakat;

3. memperkokoh perekonomian rakyat sebagai dasar kekuatan dan ketahanan perekonomian nasional dengan Koperasi sebagai sokogurunya;

4. berusaha untuk mewujudkan dan mengembangkan perekonomian nasional yang merupakan usaha bersama berdasar atas asas kekeluargaan dan demokrasi ekonomi.

Aspek legalitas dan pembinaan koperasi menjadi fokus pengawasan koperasi saat ini. Pasalnya, banyak kasus koperasi yang mencuat saat ini, akibat melalaikan aspek legalitas seperti perijinan, badan usaha, AD/ART maupun kepatuhan melakukan Rapat Anggota Tahunan (RAT).

Koperasi Pesona Mandiri didirikan sejak 2015 dan telah memiliki anggota lebih dari 100 orang, yang terdiri dari para pedagang di sekitaran stasiun pasar minggu. Yang rata-rata anggota ini memilih untuk bergabung menjadi anggota Koperasi dikarenakan koperasi Pesona Mandiri telah membantu mereka terbebas dari jeratan hutang kepada rentenir. Dengan adanya koperasi tersebut para anggota lebih mudah memperoleh bantuan permodalan dan terhindar dari kewajiban pembayaran bunga yang tidak masuk akal. Perutaran uang yang di kelola oleh koperasi Pesona Mandiri lebih kurang sebesar 1,4 Milyar setiap tahunnya. Sehingga koperasi tersebut memiliki potensi sangat besar untuk bias terus berkembang dan terus membantu masyarakat.

Pembangunan koperasi sebagai wadah kegiatan ekonomi rakyat diarahkan agar semakin memiliki kemampuan menjadi badan usaha yang efisien, serta menjadi gerakan ekonomi rakyat yang tangguh dan berakar dalam masyarakat. Koperasi sebagai badan usaha yang makin mandiri harus mampu memajukan kesejahteraan ekonomi rakyat, yang didukung oleh jiwa dan semangat yang tinggi dalam perwujudan demokrasi ekonomi berdasarkan Pancasila dan Undang-undang Dasar Negara Republik 


\section{Loyalitas Kreativitas Aldi Masyarakat Kreatil}

P-ISSN 2722-2101, E-ISSN 2722-4201

Program Studi Ekonomi Manajemen Universitas Pamulang

Jurnal LOKABMAS Kreatif Vol. 01, No. 03, Hal.53-62

Email:jurnalkreatif.manajemen@gmail.com
Indonesia tahun 1945. Keberadaan koperasi sebagai badan hukum telah membawa perubahanperubahan ke arah yang lebih maju. Dimana dengan berpedoman kepada Undang- undang No. 25 tahun 1992, koperasi terus mengembangkan potensinya ke arah usaha yang lebih besar, melalui perluasan jaringan usaha koperasi, pemilikan saham dan keterkaitan dengan usaha negara dan swasta Hingga akhirnya hakikat dari pada koperasi sebagai wadah perekonomian untuk meningkatkan kesejahteraan masyarakat dapat dipenuhi sebagaimana mestinya. Keuntungan yang bisa didapat kepada koperasi yang sudah berbadan hukum diantaranya yaitu dilindungi oleh hukum, lebih aman, ada pembinaan serta jika ada alokasi dana untuk pembiayaan koperasi maka bisa mendapatkannya.

Menurut Pasal 1 angka 1 dan Pasal 9 Undang-Undang Nomor 25 Tahun 1999 tentang Perkoperasian, sehingga dengan berbadan hukum, diperoleh manfaat-manfaat koperasi sebagai berikut:

1. Peningkatan Daya Tawar (Burgaining Power) mereka terhadap pihak ketiga.

2. Menjamin pemasukan Bahan Baku.

3. Memperoleh keuntungan yang disebabkan karena bisa beroperasi secara besar-besaran.

4. Dapat menurunkan biaya transaksi (transaction cost) dan dapat meningkatkan kemampuan bersaing terhadap pihak ketiga, jika dalam usahanya dapat mengadakan integrasi secara vertical maupun horizontal.

Dari uraian di atas dapat disimpulkan bahwa legalitas koperasi menjadi badan hokum sangat lah penting. Bukan hanya bagi koperasi tetapi juga bagi para anggotanya. Sehingga sudah sepatutnya koperasi yang memiliki daya guna dan manfaat tinggi di dorong agar dapat semakin berkembang dan memberi manfaat semakin luas.

\section{RUMUSAN MASALAH}

Dengan mempertimbangkan latar belakang yang telah di jelaskan diatas kami berinisiatif untuk membentuk pengabdian masyarakat bagi pengurus dan anggota Koperasi Pesona Mandiri Pasar Minggu, Jakarta Selatan mengenai legalisasi koperasi agar para pengurus juga anggota koperasi terbuka wawasannya terkait dengan urgensi legalisasi koperasi mereka sendiri. Agar dapat mendorong Koperasi Pesona Mandiri dapat segera di legalisasikan.

\section{TUJUAN PELAKSANAAN}

1. Memberikan edukasi mengenai badan hukum dan legalisasi koperasi;

2. Memberikan pengetahuan mengenai cara mendaftarkan koperasi menjadi badan hukum.

\section{TINJAUAN PUSTAKA}

\section{Koperasi}

Koperasi secara etimologi berasal dari kata cooperation, terdiri dari kata co yang artinya bersama dan operation yang artinya bekerja atau berusaha. Jadi kata cooperation dapat diartikan bekerja bersama-sama atau usaha bersama untuk kepentingan bersama. Secara umum koperasi dipahami sebagai perkumpulan orang yang secara sukarela mempersatukan diri untuk memperjuangkan peningkatan kesejahteraan ekonomi mereka, melalui pembentukan sebuah perusahaan yang dikelola secara demokratis.

Berikut ini adalah beberapa pengertian koperasi sebagai pegangan untuk mengenal koperasi lebih jauh. Koperasi didirikan sebagai persatuan kaum yang lemah untuk membela keperluan hidupnya. Mencapai keperluan hidupnya dengan ongkos yang semurah-murahnya, itulah yang dituju. Pada koperasi didahulukan keperluan bersama, bukan keuntungan.

Koperasi adalah suatu perkumpulan orang, biasanya yang memiliki kemampuan ekonomi terbatas, yang melalui suatu bentuk organisasi perusahaan yang diawasi secara demokratis, masing-masing memberikan sumbangan yang setara terhadap modal yang diperlukan, dan bersedia menanggung risiko serta menerima imbalan yang sesuai dengan usaha yang mereka lakukan. 


\section{Loyalitas Kreativitas Aldi Masyarakat Kreatif}

P-ISSN 2722-2101, E-ISSN 2722-4201

Program Studi Ekonomi Manajemen Universitas Pamulang

Jurnal LOKABMAS Kreatif Vol. 01, No. 03, Hal.53-62

Email:jurnalkreatif.manajemen@gmail.com
Definisi koperasi di Indonesia termuat dalam UU No. 25 tahun 1992 tentang Perkoperasiaan yang menyebutkan bahwa koperasi adalah badan usaha yang beranggotakan orang-orang atau badan hukum koperasi dengan melandaskan kegiatannya berdasarkan prinsip koperasi, sekaligus sebagai gerakan ekonomi rakyat yang berdasarkan asas kekeluargaan.

\section{Badan Hukum}

Lapangan usaha koperasi Indonesia berdasarkan Pasal empat puluh tiga (43) dan Pasal empat puluh empat (44) UU Perkoperasian beserta penjelasannya. Koperasi Indonesia dapat bergerak disemua bidang kehidupan ekonomi dan berperan utama dalam kehidupan ekonomi rakyat. Kehidupan ekonomi rakyat adalah semua kegiatan ekonomi yang dilaksanakan dan menyangkut kepentingan orang banyak, seperti yang diamanatkan oleh Pasal tiga puluh tiga (33) UUD 1945. Koperasi dapat menghimpun dana dan menyalurkan melalui kegiatan usaha simpan pinjam dari dan untuk : anggota koperasi yang bersangkutan, koperasi lain dan/atau anggotanya. Kegitan usaha simpan pinjam dapat dilaksanakan sebagai salah satu atau satu-satunya kegiatan usaha koperasi. Pelaksanaan kegiatan usaha simpan pinjam oleh koperasi diatur lebih lanjut dengan peraturan pemerintah.

Berdasarkan lapangan usaha di atas maka koperasi termasuk dalam lembaga keuangan, karena berbentuk lembaga keuangan maka koperasi harus berbadan hukum. Badan hukum adalah suatu badan atau perkumpulan yang dapat memiliki hak-hak dan melakukan perbuatan seperti seorang manusia, serta memiliki kekayaan sendiri, dapat digugat dan mengggugat di depan hakim. Badan hukum diakui sebagai subyek hukum didasarkan pada pandangan atau teori hukum yang menganggap (deem theory) bahwa sekelompok orang yang mendirikan perkumpulan dapat memiliki hakhak yang dipersamakan dengan manusia untuk melakukan hubungan dalam lalu lintas hukum. Menurut Wirjono Prodjodikoro ada perkumpulan yang berbadan hukum dan banyak yang tidak berstatus badan hukum.

Karakteristik badan hukum adalah memiliki kekayaan sendiri, anggaran dasar disahkan oleh pemerintah, dan diwakili oleh pengurus. Koperasi akan memperoleh status badan hukum setelah akta pendiriannya disahkan oleh pemerintah, dalam hal ini pemerintah adalah Kementrian Koperasi dan Usaha Kecil dan Menengah (UKM). Status badan hukum pada koperasi juga mengakibatkan koperasi memiliki kekayaan yang terpisah dari anggotanya, jadi pertanggungjawaban anggota koperasi pada pihak ketiga hanya sebatas investasi yang diberikan.

Koperasi adalah salah satu alternatif yang sangat baik untuk digunakan karena koperasi adalah badan usaha yang melakukan kegiatan berdasarkan prinsip koperasi sekaligus sebagai penggerak ekonomi rakyat dengan memperhatikan kedudukan dan tujuan koperasi, maka peran koperasi sangat penting dalam menumbuhkan dan mengembangkan potensi ekonomi rakyat serta dalam mewujudkan kehidupan demokrasi ekonomi yang mempunyai ciri-ciri : demokratis, kebersamaan, kekeluargaan, dan keterbukaan. Dalam Pasal tiga (3) UU Perkoperasian disebutkan bahwa tujuan koperasi Indonesia adalah memajukan kesejahteraan anggota pada khususnya dan masyarakat pada umumnya serta ikut membangun tatanan perekonomian nasional dalam rangka mewujudakan masyarakat yang maju, adil, dan makmur berlandaskan Pancasila dan Undang-Undang Dasar 1945.

\section{Proses Legalitas Koperasi}

Untuk mendirikan koperasi terdapat sejumlah syarat yang harus dipenuhi. Berikut persyaratannya:

a. Koperasi primer harus didirikan oleh minimal 20 orang yang punya kegiatan dan kepentingan ekonomi yang sama. 
Loyalitas Kreativitas

Aldi Masyarakat Kreatif
P-ISSN 2722-2101, E-ISSN 2722-4201

Program Studi Ekonomi Manajemen Universitas Pamulang

Jurnal LOKABMAS Kreatif Vol. 01, No. 03, Hal.53-62

Email:jurnalkreatif.manajemen@gmail.com
Sedangkan pendiri koperasi sekunder minimal 3 badan hukum Koperasi

b. Para Pendiri atau kuasa pendiri koperasi mengajukan permintaan pengesahan akta pendirian koperasi secara tertulis dan/atau secara elektronik kepada Menteri Koperasi dan UKM

c. Pengajuan pengesahan akta pendirian koperasi perlu melampirkan: 2 rangkap akta pendirian koperasi dan satu di antaranya bermaterai; berita acara Rapat Pendirian Koperasi, termasuk pemberian kuasa untuk mengajukan permohonan pengesahan; surat bukti penyetoran modal yang paling sedikit sebesar simpanan pokok; dan rencana awal kegiatan usaha Koperasi.

d. Berita acara Rapat Pendirian Koperasi harus dilengkapi: daftar hadir rapat pendirian; foto copy KTP pendiri sesuai daftar hadir; surat kuasa pendiri; surat rekomendasi instansi terkait dengan bidang usaha yang akan dijalani

e. Untuk koperasi sekunder harus ditambahkan dokumen: Hasil berita acara rapat pendirian koperasi dan surat kuasa koperasi primer dan/atau koperasi sekunder untuk pendirian koperasi sekunder; Keputusan pengesahan badan hukum koperasi primer dan/atau sekunder calon anggota; Koperasi primer dan/ atau sekunder calon anggota melampirkan Nomor Pokok Wajib Pajak (NPWP) aktif

f. Ada syarat tambahan untuk pendirian koperasi simpan pinjam dan koperasi simpan pinjam syariah (bisa dilihat di pasal 10 ayat 5 dan 6 Permen Koperasi dan UKM 9/2018).

Mengenai tahapan dan tata cara pendirian koperasi sesuai diatur Permen Koperasi dan UKM Nomor 9 Tahun 2018 adalah:

a. Perencanaan Pendirian Koperasi Ada minimal 20 anggota (koperasi primer) Menentukan tempat kedudukan koperasi Punya modal sendiri (minimal dari simpanan pokok, bisa ditambah simpanan wajib, hibah) Tentukan nama koperasi (paling sedikit 3 kata setelah frasa koperasi) Buat rencana awal usaha Ada calon pengurus dan pengawas

b. Penyampaian rencana dan konsultasi ke dinas (daerah) atau pusat (Kementerian)

c. Rapat Pendirian Koperasi Dihadiri calon pendiri, minimal 20 orang (untuk koperasi primer) Dihadiri pejabat penyuluh dari dinas atau kementerian Dapat dihadiri notaris Rapat pendirian koperasi dipimpin oleh pimpinan dan sekretaris yang ditunjuk para pendiri Rapat memilih pengurus dan pengawas serta menentukan masa bhaktinya Rapat pendirian koperasi membahas rancangan anggaran dasar Hasil rapat dibuat dalam notulen rapat dan/atau Berita Acara Rapat Notulen rapat atau berita acara rapat dituangkan dalam rancangan Anggaran Dasar Koperasi Notaris mencatat kesepakatan tentang pokokpokok hasil pembahasan dalam rapat pendirian Pokok-pokok hasil pembahasan dirumuskan dalam Akta Pendirian Koperasi

d. Verifikasi Nama Koperasi Notaris mengonfirmasi penetapan nama koperasi pada Sistem Administrasi Layanan Badan Hukum Koperasi (Sisminbhkop) Koperasi yang telah memperoleh persetujuan nama wajib mengajukan permohonan Akta Pendirian di dalam waktu paling lama 30 hari

e. Pengajuan Pengesahan Akta Pendirian Koperasi Untuk mendapatkan pengesahan akta pendirian Koperasi, pendiri atau kuasa para pendiri mengajukan permintaan pengesahan secara tertulis kepada menteri melalui Sisminbhkop Permintaan pengesahan diajukan dengan melampirkan: 2 rangkap akta pendirian Koperasi, dan satu di antaranya bermaterai cukup; Berita acara rapat pendirian Koperasi, termasuk pemberian kuasa untuk mengajukan permohonan pengesahan apabila ada; 
Loyalitas Kreativitas

Aldi Masyarakat Kreatif
P-ISSN 2722-2101, E-ISSN 2722-4201

Program Studi Ekonomi Manajemen Universitas Pamulang

Jurnal LOKABMAS Kreatif Vol. 01, No. 03, Hal.53-62

Email:jurnalkreatif.manajemen@gmail.com bukti penyetoran modal minimal sebesar simpanan pokok; dan rencana awal kegiatan usaha Koperasi

f. Verifikasi Dokumen Permohonan Lampiran permohonan Pengesahan Akta Pendirian Koperasi yang diajukan oleh pemohon dilengkapi persyaratan dan berkas dokumen pendukung (untuk memenuhi syarat pendirian koperasi) Dokumen diserahkan pemohon untuk diperiksa dan diteliti oleh pejabat berwenang melalui Sisminbhkop Pejabat yang berwenang menerbitkan tanda terima kepada pemohon, setelah dokumen dinyatakan lengkap dan memenuhi persyaratan Berkas dokumen dan surat tanda terima disimpan oleh Notaris

g. Mekanisme di Sisminbhkop Permohonan pengesahan Akta Pendirian Koperasi dilakukan secara tertulis dengan mengisi Form Isian Akta Pendirian Koperasi sebagaimana tersedia pada Sisminbhkop Permohonan pengesahan Akta Pendirian Koperasi diajukan pemohon dengan cara memindai dan mengunggah dokumen Administrator Sisminbhkop memeriksa format isian dan dokumen dari pemohon Apabila format isian tidak sesuai dengan ketentuan peraturan perundangundangan, pejabat berwenang memberitahukan alasan penolakan kepada pemohon secara elektronik Penolakan dapat dikoreksi atau diperbaiki pemohon dan selanjutnya disampaikan kembali melalui Sisminbhkop

h. Pengesahan Pendirian Koperasi Menteri menerbitkan keputusan pengesahan Akta Pendirian koperasi dalam jangka waktu paling lama 7 hari terhitung sejak pengisian format isian akta pendirian dan dokumen yang diunggah dinyatakan telah dipenuhi secara lengkap dan benar Keputusan Menteri disampaikan kepada Pemohon secara elektronik. Notaris bisa langsung mencetak Surat Keputusan
Menteri tentang pengesahan Akta Pendirian Koperasi Keputusan pengesahan Akta Pendirian Koperasi dihimpun Kementerian Koperasi dan UKM dan dicatat dalam Buku Daftar Umum Koperasi dan dapat dibuat secara elektronik Kementerian Koperasi dan UKM wajib menyampaikan salinan keputusan pengesahan Akta Pendirian Koperasi kepada Dinas (provinsi/kabupaten/kota) di lokasi kedudukan koperasi.

\section{HASIL DAN PEMBAHASAN}

Koperasi adalah salah satu alternatif yang sangat baik untuk digunakan karena koperasi adalah badan usaha yang melakukan kegiatan berdasarkan prinsip koperasi sekaligus sebagai penggerak ekonomi rakyat dengan memperhatikan kedudukan dan tujuan koperasi, maka peran koperasi sangat penting dalam menumbuhkan dan mengembangkan potensi ekonomi rakyat serta dalam mewujudkan kehidupan demokrasi ekonomi yang mempunyai ciri-ciri : demokratis, kebersamaan, kekeluargaan, dan keterbukaan. Dalam Pasal tiga (3) UU Perkoperasian disebutkan bahwa tujuan koperasi Indonesia adalah memajukan kesejahteraan anggota pada khususnya dan masyarakat pada umumnya serta ikut membangun tatanan perekonomian nasional dalam rangka mewujudakan masyarakat yang maju, adil, dan makmur berlandaskan Pancasila dan Undang-Undang Dasar 1945.

Koperasi Pesona Mandiri sebagai salah satu penggerak UMKM di sekitar wilayah Pasar Minggu, memiliki fungsi sebagai pendorong eksistensi dari para UMKM tersebut. Dengan adanya Koperasi Pesona Mandiri, para pelaku usaha di ajarkan mengenai kegiatan menabung yang walaupun sederhana tetapi masyarakat kita sering lupa melakukannya. Selain itu, sebagai bantuan permodalan bagi UMKM. Yang rata-rata mereka tidak bankcable sehingga kesulitan untuk melakukan peminjaman uang kepada bank. Proses peminjaman yang memakai system kekeluargaan sesuai dengan prinsip koperasi, 


\section{Loyalitas Kreativitas Aldi Masyarakat Kreatif}

P-ISSN 2722-2101, E-ISSN 2722-4201

Program Studi Ekonomi Manajemen Universitas Pamulang

Jurnal LOKABMAS Kreatif Vol. 01, No. 03, Hal.53-62

Email:jurnalkreatif.manajemen@gmail.com membuat pelaku usaha tidak terbebani dan sangat terbantu untuk mengembangkan usahanya.

Tidak main-main bahwa setiap tahunnya Koperasi Pesona Mandiri dapat mengeluarkan pinjaman sebesar hamper 700 juta rupiah. Artinya Koperasi ini sangat berpotensi untuk besar dan juga sangat di butuhkan masyarakat. Selain itu pelaku usaha juga terhindar dari yang namanya lintah darat, meminjamkan uang dengan bunga yang sangat besar. Alhasil bukan usaha semakin berkembang, UMKM malah semakin lesu dan terpuruk.

Tim Abdimas melihat segala potensi tersebut berusaha untuk menyempurnakan fungsi Koperasi Pesona Mandiri dengan mendorong para pengurus untuk segera melakukan pendaftaran dan melegalkan Koperasi tersebut agar berstatus badan hokum. Karena dengan statusnya yang berbadan hokum maka ada berbagai hal yang akan merubah Koperasi ke arah yang lebih positif:

1. Dengan berbadan hokum maka tanggung jawab pengurus menjadi terbatas. Sehingga ada perlindungan hokum kepada pengurus Koperasi apabila ada suatu tindak pidana dalam Koperasi

2. Dengan berbadan hokum, Koperasi dapat memperluas jenis usahanya. Dengan usaha semakin luas, maka akan semakin besar tersedia dana kredit untuk para anggota Koperasi

3. Dengan berbadan hokum maka segala kegiatan yang dilakukan Koperasi akan sah dan legal di mata hokum

Di karenakan kondisi pandemik yang menyebabkan seluruh masyarakat di haruskan di rumah dan wilayah mitra yang masuk ke dalam zona merah penyebaran Covid-19, sehingga Tim memutuskan untuk melaksanakan Abdimas dengan memanfaatkan teknologi yang ada. Tim tidak menggunakan saran Zoom atau Google Meet karena mempertimbangkan kondisi peserta dari kegiatan pengabdian ini yang merupakan pedagang pasar, yang tidak semuanya memiliki smartphone dan paham mengenai aplikasi tersebut. Sehingga Tim memutuskan untuk memakai sarana yang tidak memberatkan dan menyulitkan peserta kegiatan pengabdian ini yaitu dengan membuat video tutorial terkait syarat dan proses pendaftaran yang kami share pada grup whatsapp milik koperasi, melalui penanggung jawab koperasi tersebut. Lalu dilanjutkan dengan open diskusi melalui media whatsapp group, yang berisikan 20 peserta baik pengurus maupun anggota koperasi dan juga dua orang Tim pengabdian. Dengan begitu Tim berharap, walaupun tidak bertemu secara langsung, mitra tetap bias mendapatkan informasi yang seharusnya dan dapat bertanya kepada Tim tentang hal yang belum di pahami.

Tim memberikan pencerahan bahwasanya proses pendaftaran Koperasi tidaklah serumit dan selama yang mereka pikirkan. Waktu yang di tempuh akan setimpal dengan benefit yang akan di terima oleh Koperasi sendiri. Selain itu, Tim juga memberikan penjelasan mengenai dokumendokumen apa saja yang harus pengurus persiapkan untuk melakukan pendaftaran. Juga terkait langkah-langkah yang harus mereka tempuh dalam proses pendaftaran.

Segala proses pendaftaran bias di bantu oleh seorang Notaris dan akan dilakukan secara online. Sehingga pengurus tidak perlu kesulitan dan kebingungan lagi mengenai bagaimana, kemana dan haru apa dalam proses pendaftaran Koperasi. Yang terpenting adalah pengurus mempersiapkan segala syarat administrative dan langsung serahkan ke Notaris. Berikut alur pendaftaran Koperasi yang Tim telah berikan kepada pengurus: 


\section{Loyalitas Kreativitas \\ Aldi Masyarakat Kreatif}

P-ISSN 2722-2101, E-ISSN 2722-4201

Program Studi Ekonomi Manajemen Universitas Pamulang

Jurnal LOKABMAS Kreatif Vol. 01, No. 03, Hal.53-62

Email:jurnalkreatif.manajemen@gmail.com

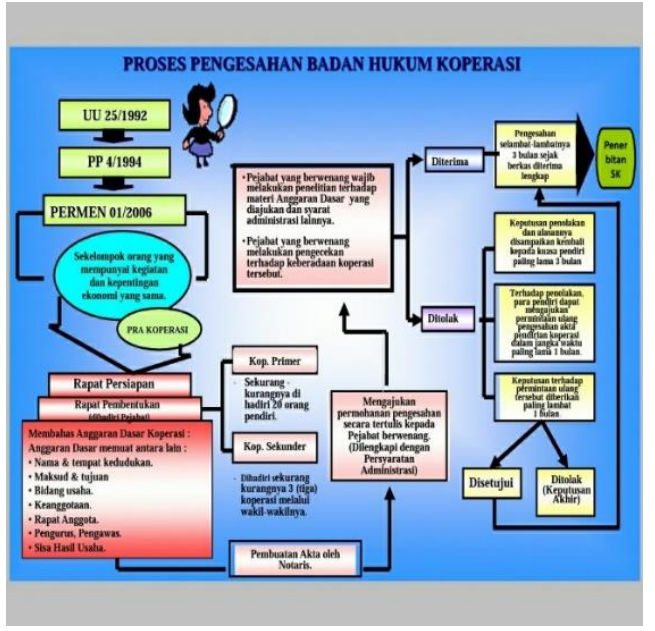

Setelah pengurus memahami proses, Tim juga memberikan motivasi dan dorongan untuk segera melakukan pendaftaran tersebut. Dengan akan membantu Pengurus untuk mengenalkan seorang Notaris di Pasar Minggu yang akan membantu dalam memproses segala alur dalam proses pendaftaran tersebut.

Di akhir kegiatan, pengurus dan Notaris tersebut sudah di bertemukan secara online dan juga berkomunikasi via whatsapp untuk membicarakan keberlanjutan proses pendaftaran Koperasi. Pengurus diminta menyiapkan semua dokumen yang diperlukan agar Notaris dapat segera memprosesnya. Saat ini Notaris masih menunggu pihak pengurus untuk menyerahkan dokumen tersebut. Tim akan terus memantau sampai dengan segala proses selesai.

\section{KESIMPULAN DAN SARAN Kesimpulan}

Simpulan dari seluruh rangkaian kegiatan yang dilakukan adalah bahwa awamnya para pengurus terkait informasi urgensi legalisasi Koperasi serta tahap-tahap dalam melakukan legalisasi atau pendaftaran tersebut. Sehingga butuh di berikan pencerahan, masukan dan motivasi agar pengurus bias terdorong untuk segera melakukan pengurusan terkait legalisasi Koperasi.

\section{Saran}

Saran yang dapat diberikan yaitu pihak koperasi harus segera melakukan pendaftaran, dengan mengumpulkan dokumen yang dibutuhkan dan segera diserahkan kepada Notaris agar dapat segera dilakukan pendaftaran.

\section{DAFTAR PUSTAKA}

Sutantya Rahardja Hadhikusuma. 2001. Hukum Koperasi Indonesia. Jakarta : PT Raja Grafindo Persada

Chidir Ali. 1999. Badan Hukum. Bandung : Penerbit Alumni

Wirjono Prodjodikoro. 1985. Hukum Perkumpulan Perseroan Dan Koperasi Di Indonesia. Bandung : Penerbit Dian Rakyat

Abdulkadir Muhammad. 2010. Hukum Perusahaan Indonesia. Bandung : PT Citra Aditya Bakti

Pasaribu, V. L. D., Sulaiman, S., Sutiman, S., Thaharudin, T., \& Purnomo, B. Y. (2020). PENGENALAN LETAK POSYANDU TERDEKAT DIKELURAHAN PISANGAN DENGAN MANAJEMEN PEMASARAN REVOLUSI 4.0 UNTUK MENINGKATKAN PENGETAHUAN MASYARAKAT LETAK DAN FUNGSI POSYANDU TERDEKAT PADA KELURAHAN PISANGAN. DEDIKASI PKM, I(1), 105-110.

Wahyu Sasongko. 2011. Dasar-Dasar Ilmu Hukum. Bandar Lampung : Universitas Lampung

https://tirto.id/tahapan-pendirian-koperasidan-syarat-pengesahan-badan-hukumnya-ekom

http://digilib.unila.ac.id/29326/3/SKRIPSI\% 20TANPA\%20BAB\%20PEMBAHASAN.pdf 
Loyalitas Kreativitas

Aldi Masyarakat Kreatif
P-ISSN 2722-2101, E-ISSN 2722-4201

Program Studi Ekonomi Manajemen Universitas Pamulang Jurnal LOKABMAS Kreatif Vol. 01, No. 03, Hal.53-62

Email:jurnalkreatif.manajemen@gmail.com
DOKUMENTASI

Foto saat Tim Melakukan Group Video Call dengan beberapa Pengurus Koperasi Pesona Mandiri

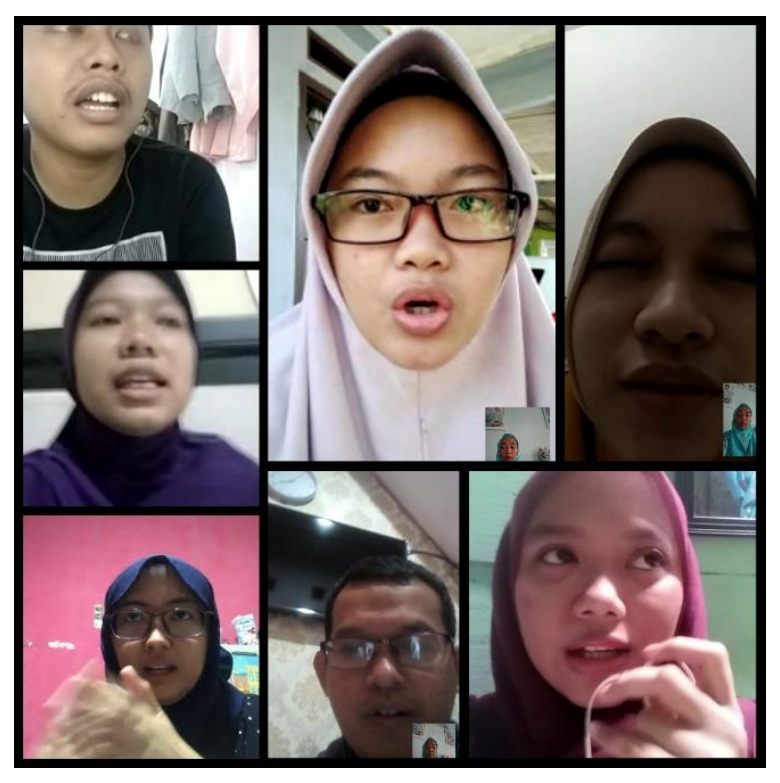

Diskusi melalui Whatsapp Group

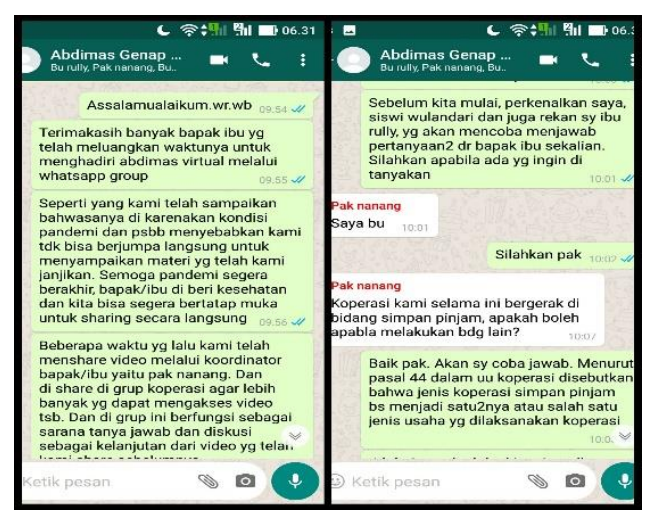

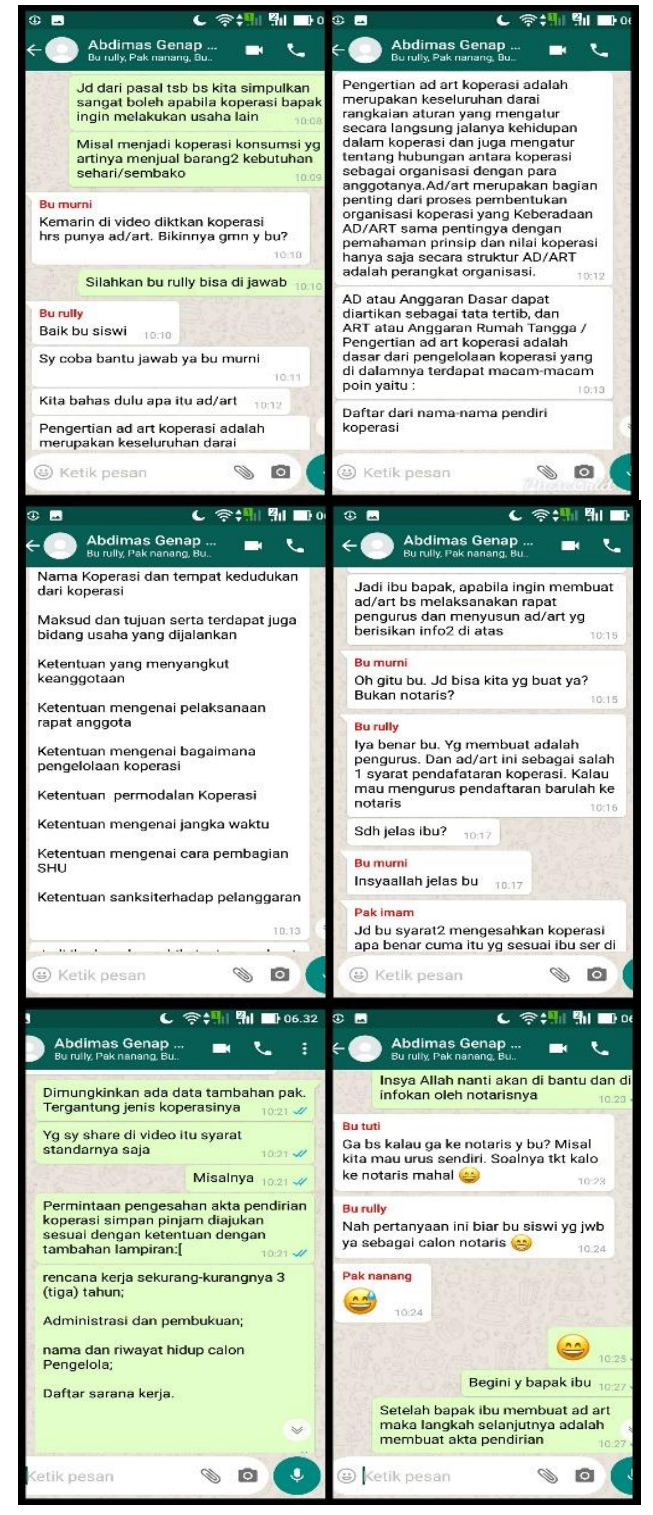




\section{Loyalitas Kreativitas \\ Aldi Masyarakat Kreatil}

P-ISSN 2722-2101, E-ISSN 2722-4201

Program Studi Ekonomi Manajemen Universitas Pamulang Jurnal LOKABMAS Kreatif Vol. 01, No. 03, Hal.53-62

Email:jurnalkreatif.manajemen@gmail.com
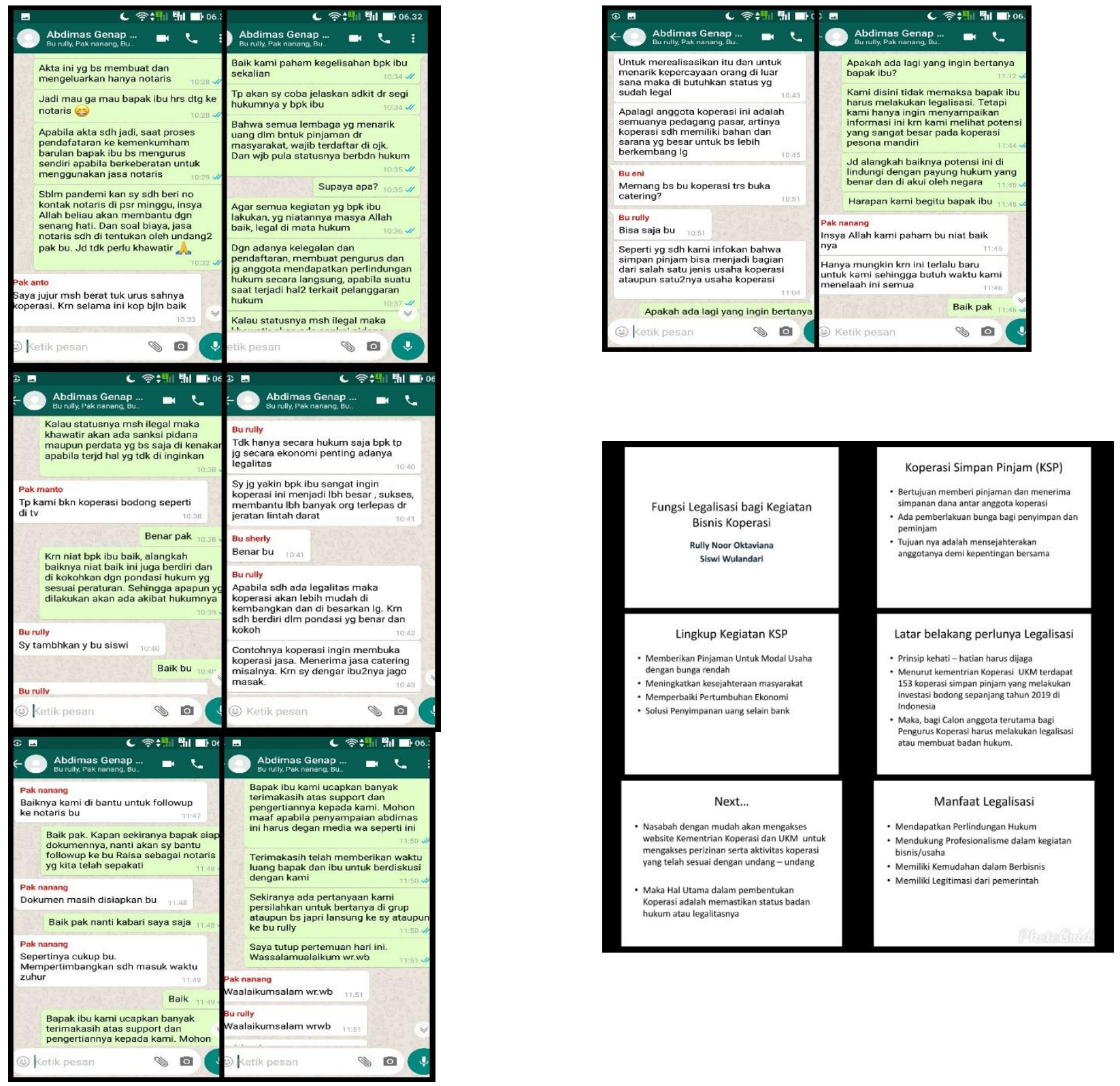

Materi yang di berikan dalam bentuk Video

PPT 